\title{
The effect of lingonberry leaves and oak cortex addition to sheep diets on pancreatic enzymes activity
}

\author{
M.P. Majewska1', J.J. Pająk, J. Skomiał, R. Miltko and B. Kowalik \\ The Kielanowski Institute of Animal Physiology and Nutrition, Polish Academy of Sciences \\ Instytucka 3, 05-110 Jabłonna, Poland
}

KEY WORDS: tannins, pancreatic-biliary juice, enzyme activity, ruminants

Received: $\quad 14$ July 2017

Revised: 17 October 2017

Accepted: 13 November 2017

${ }^{1}$ Corresponding author:

e-mail: m.majewska@ifzz.pl

\begin{abstract}
Tannins are water-soluble polyphenols with anti-nutritional properties but when supplemented at a low dose to the diets may exhibit positive effect on ruminants. Owing to great group diversity, tannins demonstrate various biological activities. They form complexes with nutrients and so they are enable to affect digestion processes. Thus, the aim of the study was to examine the effect of two types of tannins on sheep pancreatic enzymes activity. In the experiment 6 ewe of the Coloured Merino breed, fitted with catheters to the common pancreatic-biliary duct and simple cannula to the duodenum were used. Sheep were divided into 3 feeding groups for crossover design $(n=2)$, and fed control diet (CON) and two experimental diets with dried lingonberry leaves (VVI) or oak cortex (QUE) in a dose of $3 \mathrm{~g} \cdot \mathrm{d}^{-1}$, as a source of condensed and hydrolysable tannins, respectively. Non-significant effect of tannins on pancreatic-biliary juice secretion and its protein concentration was observed. In sheep fed diets with QUE addition lipase activity was increased in comparison to animals receiving VVI. An upward trend in amylase and trypsin activity after tannins addition was also found. Enriching sheep diets with additives containing tannins slightly stimulated pancreas exocrine activity. However, the inhibitory effects of tannins on endogenous protein activity, similar to the digestive enzymes inhibitors action, cannot be excluded. So, further studies on precise defining the mechanism of tannins action on enzymes activity and digestion process in ruminants are necessary.
\end{abstract}

\section{Introduction}

Tannins are water-soluble polyphenols present in many plant foods, which are known for their anti-nutritional factors - they form complexes with proteins and polysaccharides, making them unavailable for digestion (Mueller-Harvey, 2006). On the other hand, tannins supplemented at a low dose to the diet may exert beneficial effects on ruminants such as improvement of feed palatability, protection of dietary protein from degradation in rumen and reduction of ruminal methanogenesis (Soltan et al., 2012). Due to different chemical structures and various biological activities, tannins are divided into two types - condensed and hydrolysable (Schofield et al., 2001). Ruminal environment ( $\mathrm{pH} \mathrm{6-7)} \mathrm{pro-}$ motes the formation of indigestible tannin-nutrient complexes. On the other hand, changes in $\mathrm{pH}$ values occurring in the abomasum $(\mathrm{pH}<3.5)$ and distal parts of the small intestine $(\mathrm{pH}>7)$, may release nutrients from such complexes, making them susceptible for digestion (Mueller-Harvey, 2006).

In the studies on tannins, the amount, form (pure extract or part of the plant) and origin of such 
polyphenols are very important. Grela et al. (2010) showed that grass pea seeds (Lathyrus sativus L.) from the Mediterranean area, and West and Central Europe differ in the amount of tannins. Also, a positive correlation between tannins content and flower colour intensity of plant was found. Interestingly, Grela et al. (2017) examining Fabaceae plant seeds observed strong relation between tannins concentration and protein level.

The information about the influence of tanninrich diets on pancreas enzymatic activity in ruminants is scarce. Furthermore, the previous studies were mostly performed in in vitro conditions with enzymes originated from monogastric animals and humans. Inhibitory effect of tannins on the activity of digestive enzymes has been already documented (Gonçalves et al., 2007; Wang et al., 2014). The better knowledge of physiological mechanism of pancreas activity in ruminants, could be used to improve the digestion and absorption of nutrients in the duodenum.

It was hypothesized that supplementation of sheep diets with tannins may stimulate the exocrine activity of pancreas. So, the study was carried out to determine how the addition of lingonberry leaves and oak cortex - sources of condensed and hydrolysable tannins, respectively - influences sheep pancreatic enzymes activity.

\section{Material and methods}

All procedures were accepted by the Local Animal Care and Ethics Committee for Animal Experiment in Warsaw (Poland); permission No. 51/2009.

\section{Animals and diets}

The experiment was performed on 6 Coloured Merino ewe with similar body weight $(36 \pm 1.5 \mathrm{~kg})$ and age (about 2 years old), fitted with catheter to the common pancreatic-biliary duct $(5-6 \mathrm{~cm}$ behind the sphincter of Oddi) and a simple cannula to the duodenum ( $3-5 \mathrm{~cm}$ behind the estuary of pancreaticbiliary duct). The duodenal cannula was equipped with check valve to prevent from digesta withdrawal to the pancreatic-biliary duct. Catheter and duodenal cannula were connected together outside of the sheep body to ensure the constant flow of juice and bile mixture to the duodenum.

Sheep were divided into 3 feeding groups for crossover design of 2 sheep each and fed twice a day. The basal diet (group CON) consisted of hay, barley meal, soyabean meal and vitamin-mineral additives (Polfamix O-K, Trouw Nutrition Polska, Grodzisk Mazowiecki, Poland; Table 1). The experimental
Table 1. Ingredients and chemical composition of sheep basal diet ${ }^{1}$

\begin{tabular}{lc}
\hline Indices & Content \\
\hline Components, $\mathrm{g} \cdot \mathrm{kg} \mathrm{DM}^{-1}$ & 597 \\
meadow hay & 284 \\
barley meal & 98.3 \\
soyabean meal & 20.7 \\
Polfamix O-K² & \\
Chemical composition, $\mathrm{g} \cdot \mathrm{kg} \mathrm{DM}^{-1}$ & \\
organic matter & 941 \\
crude protein & \\
starch & 152 \\
crude fat & 247 \\
crude fibre & 20.0 \\
NDF & 203 \\
ADF & 511 \\
ADL & 260 \\
crude ash & 39.8 \\
Nutritive value & 58.5 \\
PDI, $\mathrm{g}$ & \\
UFV, per $\mathrm{kg}$ & 95.3 \\
SFU, per $\mathrm{kg}$ & 0.8 \\
\hline
\end{tabular}

${ }^{1}$ diet formulated according to the ruminant nutrition recommendations (IZ PIB-INRA, 2009); ${ }^{2}$ Polfamix O-K (Trouw Nutrition Polska, Grodzisk Mazowiecki, Poland) in kg: g: Ca 240, Na 60, P 120, Mg 65, Zn 2.5, Mn 3.0, vit. E 1.5, Se 0.003, Co 0.015; IU: vit. A 300.000, vit. D 30.000; ${ }^{3}$ expressed as $\mathrm{N} \times 6.25$; DM - dry matter, NDF - neutral detergent fibre, ADF - acid detergent fibre, ADL - acid detergent lignin, PDI protein digested in small intestine, UFV - feed unit for maintenance and meat production, SFU - fill unit for sheep

groups received the basal diet with the addition of dried lingonberry leaves (Vaccinium vitis-idaea L.; group VVI) or oak cortex (Quercus sp.; group QUE) at a dose of $3 \mathrm{~g} \cdot \mathrm{d}^{-1}$, representing sources of condensed and hydrolysable tannins, respectively. The diets were changed among all sheep during three periods (I, II, III; period $=14$ days) to ensure that pairs of animals received each diet in a different time.

During adaptation periods (14 days) sheep were kept in individual rearing pens with ad libitum access to water and salt licks, with no refusals observed. During collections of pancreatic-biliary juice samples animals were moved to metabolic cages.

\section{Sampling procedure}

The samples of pancreatic-biliary juice were collected during $8 \mathrm{~h}$ for 3 days. During collection the catheter and duodenal cannula were disconnected. The mixture of pancreatic juice and bile was collected every hour, weighed, and $5 \%$ of it was pooled and ice-cold. The remaining part of the pancreaticbiliary juice was slowly administered by peristaltic pump to the duodenum, not to interfere the digestion process in sheep. The samples of pancreatic-biliary mixture were stored at $-80^{\circ} \mathrm{C}$ until further analysis. 
At the end of each collection catheter and duodenal cannula were connected again. After 3 days of collection, animals were returned to the rearing pens and adapted for 14 days to the next diet.

\section{Chemical analyses}

Chemical composition of diets was determined according to AOAC International (2011). Tannins concentration was estimated with vanilin test according to Kuhla and Ebmeier (1981) and defined as catechin equivalent per $\mathrm{g}$ of dry matter (DM) additive.

The energy value of the diet was in accordance to the IZ PIB-INRA ruminant nutrition recommendations (IZ PIB-INRA, 2009).

The average secretion of pancreatic-biliary juice during 8-h collections was estimated. Total protein content in juice was measured according to Lowry et al. (1951), where bovine albumin served as a standard. The pancreatic lipase activity was determined with the use of a Lipase Activity Assay Kit (ref. EM1001, Emapol, Gdańsk, Poland). The proteases activity in juice was estimated according to Hummel (1959), after enzymes activation with enterokinase provided by Sigma-Aldrich (St. Louis, MO, USA). The TAME ( $N \alpha-p$-Tosyl-L-arginine methyl ester hydrochloride) and BTEE ( $N$-Benzoyl-LTyrosine ethyl ester) both from Sigma-Aldrich (St. Louis, MO, USA) served as substrates for trypsin and chymotrypsin, respectively. Amylase activity was measured according to Walker and Harmon (1996) and the amount of reducing sugars was compared to maltose standards.

The activity of pancreatic enzymes was expressed as $U \cdot 1^{-1}$, which means that one unit of the enzyme activity (U) equals $1 \mu \mathrm{mol}$ of the product produced per min by 1 of the pancreatic-biliary juice.

\section{Statistical analysis}

The experiment was performed as a completely randomized crossover design with 3 treatments. The obtained results were subjected to one-way analysis of variance, considering the main effect of tanninrich additives. The differences among treatments were determined using Tukey's test. Differences were declared significant at $P \leq 0.05$ and trends were discussed at $0.05<P<0.08$ (Statistica 12.0 software, StatSoft ${ }^{\circledR}$ Polska, Kraków, Poland).

\section{Results}

Lingonberry leaves and oak cortex added to sheep diets contained 10.3 and $4.0 \mathrm{mg}$ tannins, respectively (expressed as equivalent of catechin per $g$ of DM additive). The DM, total protein, starch and
Table 2. Pancreatic-biliary juice secretion, its protein concentration and enzymatic activity in sheep

\begin{tabular}{lccccc}
\hline Indices & Diet & & & \multirow{2}{*}{ SEM } & $P$-value \\
\cline { 2 - 5 } & CON & VVI & QUE & & \\
\hline $\begin{array}{l}\text { Pancreatic-biliary juice } \\
\text { secretion, } \mathrm{ml} \cdot 8 \mathrm{~h}^{-1}\end{array}$ & 517 & 511 & 498 & 34.2 & 0.581 \\
$\begin{array}{l}\text { Total protein, } \mathrm{mg} \cdot \mathrm{ml}^{-1} \\
\text { Enzymatic activity, } \mathrm{U} \cdot \mathrm{I}^{-1}\end{array}$ & 38.4 & 40.3 & 32.9 & 1.40 & 0.117 \\
$\quad$ & & & & \\
$\quad$ lipase & $124^{\mathrm{b}}$ & $135^{\mathrm{b}}$ & $209^{\mathrm{a}}$ & 9.4 & $<0.001$ \\
$\quad$ amylase & 420 & 541 & 467 & 23.1 & 0.077 \\
$\quad$ trypsin & 15.6 & 19.6 & 19.9 & 0.81 & 0.060 \\
$\quad$ chymotrypsin & 24.9 & 29.0 & 23.6 & 1.35 & 0.215 \\
\hline
\end{tabular}

${ }^{1} \mathrm{CON}$ - basal diet, $\mathrm{VVI}$ - basal diet with lingonberry leaves addition, QUE - basal diet with oak cortex addition; SEM - standard error of mean; ${ }^{\text {ab }}$ - means with different superscripts within a row are significantly different at $P \leq 0.05$

ether extract intakes of the basal diet were 919, 140, 227 and $23 \mathrm{~g} \cdot \mathrm{d}^{-1}$, respectively.

The secretion of pancreatic juice and bile (in total) ranged from 498 to $517 \mathrm{ml} \cdot 8 \mathrm{~h}^{-1}$ and the protein content amounted from 32.9 to $40.3 \mathrm{mg} \cdot \mathrm{ml}^{-1}$ (Table 2); the presence of tannins in sheep diets did not affect both parameters.

In sheep fed QUE diet the lipase activity in pancreatic-biliary juice was significantly increased $(P<0.001)$ in comparison to animals fed CON diet and those receiving additional VVI (Table 2). Moreover, the upward trend was observed in amylase activity $(P=0.077)$ in sheep fed diet with VVI addition in comparison to CON group. Both additives tended to increase trypsin activity $(P=0.060)$ in pancreaticbiliary juice, with no effect on chymotrypsin activity.

\section{Discussion}

Digestion processes occurring in duodenum are possible due to enzymes secreted by pancreas cells and intestinal lumen. In contrast to monogastric animals, in ruminants the secretion of pancreatic juice and bile is permanent because of the constant flow of digesta to the duodenum, without separating period between feeding (Croom et al., 1992).

Researches concerning the effect of diet composition on pancreatic enzymes activity in ruminants are not consistent and clear like in monogastric animals. However, it was shown that young ruminants without fully developed forestomach (fed only milk-based diet) are more sensitive to the diet modifications than older ones (Harmon, 1993). Furthermore, the mechanism of exocrine pancreas activity in those animals seems to be similar to that observed in non-ruminants. After weaning, animals fed solid diet become functional ruminants (Harmon, 1993). 
Some studies on sheep documented that pancreaticbiliary juice secretion and its protein content may depend on diet composition (Kowalik et al., 2001; Żebrowska et al., 2001), but this effect seems to be not so clear like in non-ruminant animals.

In the present study, supplementing tannin-rich additives to sheep diets increased activity of some pancreatic enzymes, which is in agreement with study assumptions. It is thought that stimulating effect of tannins on pancreatic enzymes activity may be similar to the mechanism of digestive enzymes inhibitors action. Kapica et al. (2005) showed that feeding 3 -week-old calves milk diets enriched with crude or extruded soyabean meal increased pancreatic juice secretion and trypsin activity in comparison to the control group. Soyabean meal contains anti-nutritional substances, including tannins and protease inhibitors, which may inactivate digestive enzymes and at the same time stimulate pancreatic exocrine activity. Furthermore, such findings were obtained in monogastric animals. Ahmed et al. (1991) reported that feeding growing broiler cockerels diet with increasing level of tannins, significantly increased weight of pancreas in comparison to control birds. It was probably because of higher activities of trypsin and $\alpha$-amylase. Interestingly, the inhibitory effect of dietary tannins on intestinal enzymes activity was noted.

Forming complexes with enzymatic protein by enzymes inhibitors seems to decrease the amount of active enzymes in the intestinal lumen. Therefore, pancreas is stimulated to increase pancreatic juice secretion for alignment the insufficiency of enzymes in duodenum (Fushiki and Iwai, 1989). Probably similar mechanism was observed in the present study. Tannins present in VVI and QUE could form complexes with endogenous protein, inactivate them and simultaneously stimulate pancreas to juice secretion. It should be underlined that cholecystokinin (CCK) excreted from endocrine cells of intestine epithelium, is responsible for endocrine regulation of the pancreas secretory action. CCK is released due to the monitor peptide (MP) stimulation. The presence of the active enzymes in the intestinal lumen inactivates MP, CCK and finally pancreatic juice secretion. On the other hand, the inactivation of digestive enzymes by specific inhibitors stimulates MP-CCK mechanism and increases pancreas exocrine activity (Fushiki and Iwai, 1989). The higher activity of pancreatic enzymes in the present study was probably attributed to the deliverance of the tannins-nutrients complexes from rumen to the abomasum and finally to the intestinal lumen. Acidic pH of digesta (about 5.5) is persisted within about $1.5 \mathrm{~m}$ of the initial segment of the small intestine. Such conditions favour releasing nutrients from complexes with tannins and stimulate pancreas to enzymes secretion (Waghorn et al., 1994).

In numerous studies it was shown that shortchain fatty acids, especially propionic and butyric acids, are the main factors responsible for pancreatic enzymes secretion in ruminants (Croom et al., 1992; Żebrowska et al., 2001). Thus, increased concentration of butyric and isoacids in rumen fluid in sheep supplemented with QUE diet (our unpublished data) could be also the reason of elevated activity of pancreatic lipase.

It is still lack of research concerning the effect of tannins on pancreas exocrine activity in ruminants. It was shown that feeding kids with $52 \%$ of carob pods (Ceratonia siliqua L., 5\% condensed tannins), decreased trypsin and amylase activity in faecal samples in comparison to animals fed control diet (Silanikove et al., 2006). It was noted that high amount of condensed tannins in carob may negatively affect the entire gastrointestinal tract of those animals. Results of the present study are in disagreement with this study, mainly because of the amount of tannin-rich diets supplemented to animals and different place of taking samples for enzymatic analyses.

In the study of Guilloteau et al. (2012) performed on young and adult roe deer, higher proteases (chymotrypsin and elastase II) activities than in milk-fed and weaned calves were found. Differences in the pancreatic enzymes activity between those ruminants could result from their digestive system function and feeding behaviour. Contrary to domestic ruminants like sheep and cow, roe deer prefer plants containing tannins and produce more saliva with high concentration of proline-rich proteins (PRPs). Such proteins form complexes with tannins and comprise the first line of defence against tanninrich plants. Guilloteau et al. (2012) showed that proteases activity could be closely related with PRPs secretion in saliva. In the present study insignificant changes in chymotrypsin activity after tannins supplementation were observed. Probably, it can be attributed to the low secretion of PRPs in sheep saliva, despite supplementing tannin-rich diets.

Most of the studies examining tannins action on pancreatic enzymes were performed in in vitro conditions with enzymes originated from monogastric animals. It was shown that tannins may decrease trypsin (Gonçalves et al., 2007), amylase (Miao et al., 2014) and lipase activities (Wang et al., 2014), which was not documented in the present study. It is difficult compare the results of the current study with those obtained under in vitro conditions. 
In in vitro studies it is only shown how tannins affect digestive enzymes activity in specific laboratory conditions, but what is occurring in the distal parts of the gastrointestinal tract remains unknown. Thus, the inhibitory effect of tannins on pancreatic enzymes activity cannot be excluded from the results of the present study.

\section{Conclusions}

Feeding sheep diets enriched with tannins affected exocrine pancreas activity. Although there was observed an increased activity of pancreatic enzymes after tannins addition, the inhibitory effect of polyphenols present in lingonberry leaves or oak cortex on pancreatic enzymes cannot be excluded. In the future, histological study of pancreas and pancreatic acinar cells seems to be necessary to clarify the mechanism of tannins action on endogenous protein and hence digestion in ruminants.

\section{Acknowledgements}

The work was supported by the Ministry of Science and Higher Education in Poland, Grant No. N N311 110138.

\section{References}

Ahmed A.E., Smithard R., Ellis M., 1991. Activities of enzymes of the pancreas, and the lumen and mucosa of the small intestine in growing broiler cockerels fed on tannin-containing diets. Br. J. Nutr. 65, 189-197, https://doi.org/10.1079/BJN19910080

AOAC International, 2011. Official Methods of Analysis of AOAC International. $18^{\text {th }}$ Edition. $4^{\text {th }}$ Revision. Gaithersburg, MD (USA)

Croom W.J. Jr., Bull L.S., Taylor I.L., 1992. Regulation of pancreatic exocrine secretion in ruminants: a review. J. Nutr. 122, 191-202

Fushiki T., Iwai K., 1989. Two hypotheses on the feedback regulation of pancreatic enzyme secretion. Faseb J. 3, 121-126

Gonçalves R., Soares S., Mateus N., de Freitas V., 2007. Inhibiton of trypsin by condensed tannins and wine. J. Agric. Food Chem. 55, 7596-7601, https://doi.org/10.1021/jf071490i

Grela E.R., Kiczorowska B., Samolińska W., Matras J., Kiczorowski P., Rybiński W., Hanczakowska E., 2017. Chemical composition of leguminous seeds: part I - content of basic nutrients, amino acids, phytochemical compounds, and antioxidant activity. Eur. Food Res. Technol. 243, 1385-1395, https://doi. org/10.1007/s00217-017-2849-7

Grela E.R., Rybiński W., Klebaniuk R., Matras J., 2010. Morphological characteristics of some accessions of grass pea (Lathyrus sativus L.) grown in Europe and nutritional traits of their seeds. Genet. Resour. Crop Evol. 57, 693-701, https://doi. org/10.1007/s10722-009-9505-4

Guilloteau P., Vitari F., Metzinger-Le Meuth V., Le Normand L., Romé V., Savary G., Delaby L., Domeneghini C., Morisset J., 2012. Is there adaptation of the exocrine pancreas in wild animal? The case of the Roe Deer. BMC Vet. Res. 8, 70, https://doi.org/10.1186/1746-6148-8-70
Harmon D.L., 1993. Nutritional regulation of postruminal digestive enzymes in ruminants. J. Dairy Sci. 76, 2102-2111, https://doi. org/10.3168/jds.S0022-0302(93)77545-1

Hummel B.C.W., 1959. A modified spectrophotometric determination of chymotrypsin, trypsin, and thrombin. Can. J. Biochem. Physiol. 37, 1393-1399, https://doi.org/10.1139/059-157

IZ PIB-INRA, 2009. Standards for Ruminant Feeding (in Polish). National Research Institute of Animal Production. Kraków (Poland)

Kapica M., Valverde Piedra J.L., Puzio I., Bieńko M., Szymańczyk S.E., Radzki R.P., 2005. The effect of feeding raw and extruded feed containing soyabean meal on pancreatic juice digestive enzyme activities in young calves. J. Anim. Feed Sci. 14, Suppl. 1, 263-266, https://doi.org/10.22358/jafs/70534/2005

Kowalik B., Kowalczyk J., Pająk J.J., Żebrowska T., Długołęcka Z., 2001. The influence of dietary starch level and type on the activity of pancreatic digestive enzymes in sheep. J. Anim. Feed Sci. 10, Suppl. 2, 57-63, https://doi.org/10.22358/ jafs/70034/2001

Kuhla S., Ebmeier C., 1981. Investigations of the tannin content in horse beans. I. Methods for determining condensed tannins in horse beans (in German). Arch. Tierernähr. 31, 573-588, https://doi.org/10.1080/17450398109426870

Lowry O.H., Rosebrough N.J., Farr A.L., Randall R.J., 1951. Protein measurement with the Folin phenol reagent. J. Biol. Chem. $193,265-275$

Miao M., Jiang H., Jiang B., Li Y., Cui S.W., Zhang T., 2014. Structure elucidation of catechins for modulation of starch digestion. LWT - Food Sci. Technol. 57, 188-193, https://doi. org/10.1016/j.lwt.2014.01.005

Mueller-Harvey I., 2006. Unravelling the conundrum of tannins in animal nutrition and health. J. Sci. Food Agric. 86, 2010-2037, https://doi.org/10.1002/jsfa.2577

Schofield P., Mbugua D.M., Pell A.N., 2001. Analysis of condensed tannins: a review. Anim. Feed Sci. Technol. 91, 21-40, https:// doi.org/10.1016/S0377-8401(01)00228-0

Silanikove N., Landau S., Or D., Kababya D., Bruckental I., Nitsan Z., 2006. Analytical approach and effects of condensed tannins in carob pods (Ceratonia siliqua) on feed intake, digestive and metabolic responses of kids. Livest. Sci. 99, 29-38, https:// doi.org/10.1016/j.livprodsci.2005.05.018

Soltan Y.A., Morsy A.S., Sallam S.M.A., Louvandini H., Abdalla A.L., 2012. Comparative in vitro evaluation of forage legumes (prosopis, acacia, atriplex, and leucaena) on ruminal fermentation and methanogenesis. J. Anim. Feed Sci. 21, 759-772, https://doi.org/10.22358/jafs/66148/2012

Waghorn G.C., Shelton I.D., McNabb W.C., McCutcheon S.N., 1994. Effects of condensed tannins in Lotus pedunculatus on its nutritive value for sheep. 2. Nitrogenous aspects. J. Agric. Sci. 123, 109-119, https://doi.org/10.1017/S0021859600067836

Walker J.A., Harmon D.L., 1996. Technical note: A simple, rapid assay for a-amylase in bovine pancreatic juice. J. Anim. Sci. 74, 658-662, https://doi.org/10.2527/1996.743658x

Wang S., Dong S., Zhang R., Shao H., Liu Y., 2014. Effects of proanthocyanidins on porcine pancreatic lipase: Conformation, activity, kinetics and thermodynamics. Process Biochem. 49, 237-243, https://doi.org/10.1016/j.procbio.2013.10.018

Żebrowska T., Kowalczyk J., Pajak J.J., Długołęcka Z., 2001. The influence of dietary protein and fibre on bile-pancreatic secretion in sheep. J. Anim. Feed Sci. 10, 619-626, https://doi. org/10.22358/jafs/68013/2001 